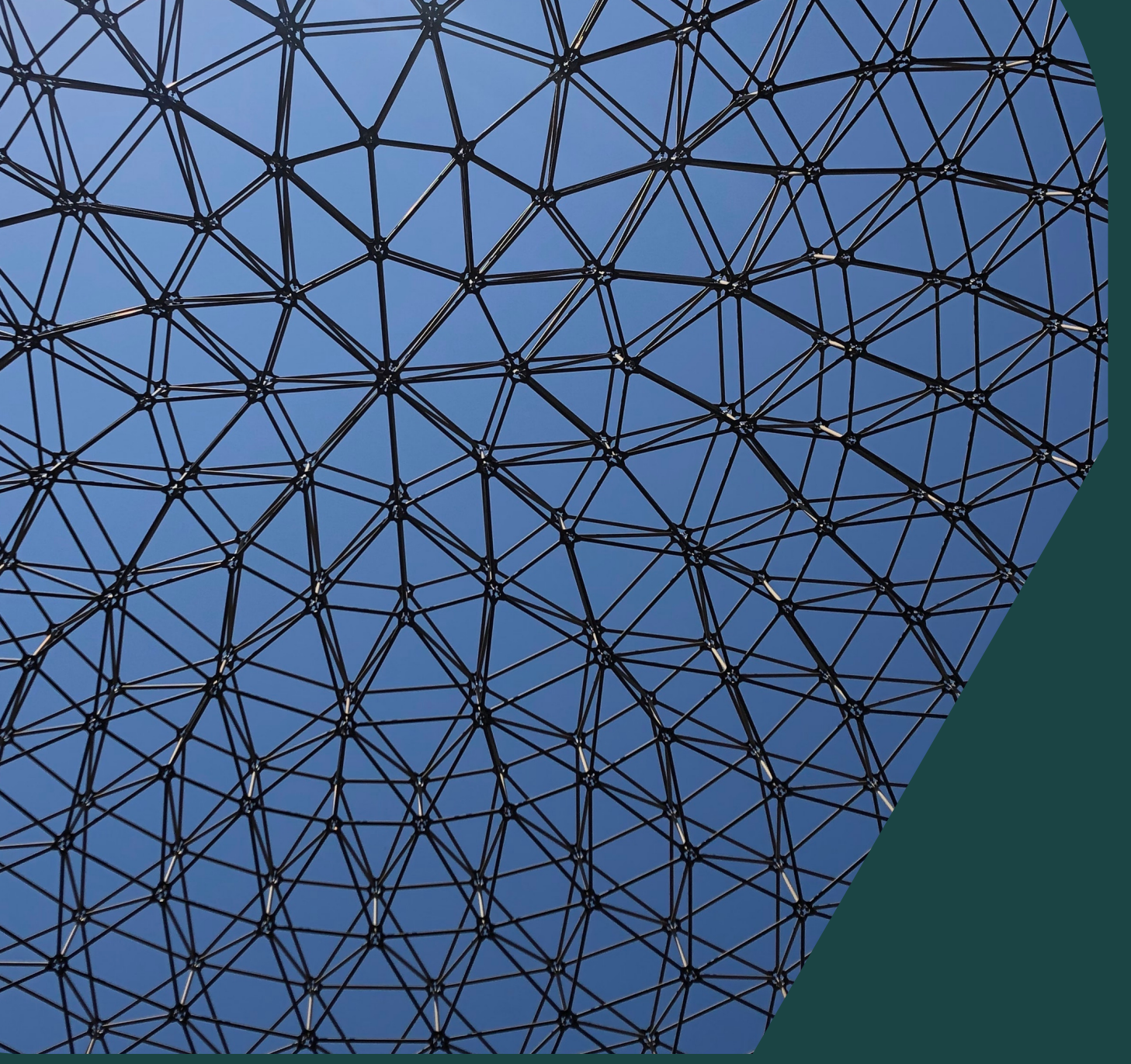

INTELLECTUAL DIMENSIONS OF MADINIAN POLITY AND ITS IMPLICATION FOR ISLAMIC GOVERNANCE: LESSONS FROM THE EARLY HISTORY OF ISLAM

Thought Paper No. 13, 2021

The Journal of Islamic Governance

AUTHOR

Senad Mrahorović 


\title{
Intellectual Dimensions of Madinian Polity and its Implication for Islamic Governance: Lessons from the Early History of Islam
}

Senad Mrahorović ${ }^{1}$

\begin{abstract}
The very first verse revealed to the Prophet of Islam namely Read in the name of your Lord implied the concept of knowledge that corresponds with the intellectual attestation of the first article of Islamic faith, that is, the belief in the unity of God, which for its part requires a specific kind of knowledge related to the Divine. With the same token, the Revelation continued to provide the Prophet hes perfectly transformed into the nucleus based on which the first Islamic state known as the Madinian polity was firmly established. Hence, in this paper, the analysis will cover the intellectual dimensions of the Madinian polity portrayed here in three essential aspects: the revelation as the principal source of knowledge, the affirmation as the intellectual and practical application of knowledge, and the manifestation as the individual and communal reflection of knowledge. I will argue that the said aspects as they were displayed in the Madinian polity are the core factors that underpin the Islamic governance as such.
\end{abstract}

Keywords: knowledge, revelation, spirituality, Madīnian polity, Islamic governance.

1 The author is a lecturer at Sultan Omar 'Ali Saifuddien Centre for Islamic Studies (SOASCIS), Universiti Brunei Darussalam (UBD), Negara Brunei Darussalam.senad.mrahorovic@ubd.edu.bn. 


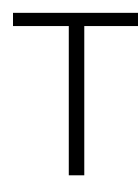

he concept of Islamic governance in the political and socio-economic context is rather a reflection of the power or domination by which one is able to manage his or herself in accordance with certain ideals, laws, or principles. The latter, within the Islamic framework, is expressed intellectually in the notion of Tauhid, followed by other doctrines of Islam, namely, angelology, revelation, prophecy, eschatology, and divine destiny, in addition to ontology, anthropology, and cosmology all of which represent the principal aspects of the Islamic worldview. On the practical level within the said worldview, a Muslim is required to exercise a specific form of reverence typified in the pillars of Islam i.e., Shahādah (the testimony of faith), Șalāh (prayer), Șaum (fasting), Zakāt (religious tax) and Hajj (pilgrimage) as an individual or collective devotion to God, the Supreme Authority to whom every segment of the created universe is unconditionally devoted albeit in diverse ways and degrees. These doctrines and pillars are further being supplemented by Islamic ethics, which to a certain extent, determine the legitimacy of the former in social, political, and economic domains that Islamic governance traditionally implies and reflects.

From the Islamic point of view, the Qur'ānic revelation is the principal container of everything Islamic and therefore of the aforementioned intellectual, practical, and ethical dimensions that are expressed either on the individual or the social level under conditions provided by a system of governance, be it Islamic or secular. In this regard, the fundamental ideas upon which a specific worldview is designed are being reflected on multiplied levels whether one has in mind an organised society governed by the set of rules and regulations known as polity or state or an individual whose physiological or psychological conditions are also called a state. In either case, the nature of sources from which ideas flow and of an intellectual capacity to grasp and process those ideas privately or publicly will determine the final outcome of a state in all its inward and outward dimensions. Thus, in the following pages our attempt is to analyse the Qur'ânic revelation as the essential source of knowledge in Islam, the realisation of different modes of such knowledge, and its reflection in the context of Madinian polity as the first Islamic state.

\section{Revelation}

The notion of revelation (wahy) generally refers to the Divine ways of communication with man, and other created beings. ${ }^{1}$ In its more specific meaning, the wahy is understood as

\footnotetext{
1 Abdullah Saeed, The Qur'an: An Introduction (London: Routledge, 2008), pp. 22-30. The verse stating that your Lord revealed unto the bee..." (the Qur'ān, 16:68) is understood to refer to the Divine inspiration or knowledge revealed to it, which reflects a kind of the Divine
} 
"the Word of God which is communicated to his prophets and messengers. It can also mean the scripture as revealed to particular prophets." Apart from the previous revelations such as Taurāt, Zabūr, and Injīl, Muslims consider the Qur'ān as the final revelation to all humanity, revealed to the Prophet Muhammad as as the Seal of prophecy and the Mercy to all worlds. Defined as "the verbatim word of God, revealed during the twenty years of the prophetic mission of the Prophet Muhammad through the agency of the Archangel Gabriel (Jibrit or Jabrā'il),"”2 the Qur'ān represents the essential source of Islam. As such, it is complemented by the Sunnah of the Prophet source of Islam. ${ }^{3}$

In Islam, the Qur'ān is regarded as the source of all knowledge, that is, the principal foundation of every aspect of intellection, contemplation, and reflection manifested in every possible way, be it intellectually, spiritually, and scientifically or poetically, artistically and architecturally, regardless of time and space. Numerous verses of the Qur'ān are impregnated with words and phrases that directly or symbolically denote concepts such as knowledge, thought, comprehension, and its various derivatives. Only the notion of knowledge in its numerous connotations is mentioned over seven hundred times. ${ }^{4}$ These concepts are contextually portrayed in correlation with God-consciousness, piety, and devotion to God, or rather submission to Him. Therefore, the Qur'ân is not only the source of knowledge, but also an inspiration for the righteous deeds as a manifestation of such a virtuous knowledge on an individual or collective level, which in return is rewarded with further enlightenment as the Qur'ān states: Our Lord, and send among them a messenger from themselves who will recite to them Your verses and teach them the Book and wisdom and purify them.... ${ }^{5}$

The above verse clearly illustrates tripartite dimensions of the Qur'ān, namely, the content (verses) of the Book, its recitation/teaching, and the purification as the final outcome that transcends one's intellection and deeds into a spiritual realm, where an idea becomes the actualisation, a contemplation becomes the realisation, by Divine will. In other words, the

\footnotetext{
communication other than that intended to human beings. See further Seyyed Hossein Nasr (Ed.), The Study Quran: A New Translation and Commentary (New York: HarpenOne, 2015), pp. 674-676.

1 Oliver Leaman (Ed.), The Qur'ān: An Encyclopedia (London: Routledge, 2006), pp. 540.

2 Seyyed Hossein Nasr (Ed.), Ibid, pp. xxiii.

3 Mohammad Hashim Kamali, Principles of Islamic Jurisprudence [Second Revised Edition] (Kuala Lumpur: Ilmiah Publishers, 2007$)$, pp. 48-50.

4 Franz Rosenthal, Knowledge Triumphant: The Concept of Knowledge in Medieval Islam (Leiden: Brill, 2007), pp. 70-71.

5 The Qur'ān, 2:129.
} 
Qur'ān is not only a Book' (al-Kitāb) containing knowledge, that is, "ideas' and 'thoughts' leading towards a concentration upon the truth [al-Haqq$\left.{ }^{2}\right]$ contained in them"3; it is also a Criterion ${ }^{4}$ (al-Furqān) in as much as its divinely inspired content aids a reader to distinguish between right and wrong, truth and falsehood; finally the Qur'ân is a Wise [Book $]^{5}$ (al-Hakim) that purifies a believer with its sacred words and verses also called Remembrance (Dhikr), Right Guidance (Hudā'), Healing (Shifä') and Light (Nür) among other names. ${ }^{6}$ In addition to this written form of the Qur'ānic revelation known as al-Qur'ān al-Tadwīnī (the recorded Qur'ān), there is also al-Qur'ān al-Takwīni (the cosmic Qur'ān) or the 'Qur'ān of creation' referring to the natural phenomena which the Qur'ân often addresses as the point of observation and reflection, ${ }^{7}$ a point that represents the crucial link between human beings and nature on the one hand, and natural sciences and religion on the other hand. ${ }^{8}$

Further analysis of the Qur'ân divulges, even more, the connection between faith (religion), intellection (philosophical and scientific investigation), and devotion (spiritual perfection), all of which are prescribed by the Qur'ān and at the same time 'preconditioned' by the necessity of certain degree of knowledge. For instance, the verses that contain the expression of Divine unity are usually revealed in the context of knowledge and submission to God, as a requisite for the proper grasping of that unity: So know, that there is no deity except Allah... ${ }^{9}$ or $\ldots$...There is no deity except Me, so worship Me ${ }^{10}$ The recognition of Divine unity elsewhere has been directly ascribed to those who possess knowledge i.e. scholars, scientists, and devotees: Allah witnesses that there is no deity except Him, and [so do] the angels and those of knowledge - [that He is] maintaining [creation] in justice.... ${ }^{11}$

\footnotetext{
This is the Book about which there is no doubt, a guidance for those conscious of Allah (The Qur'ān, 2:2).

2 ....These are the verses of the Book; and what has been revealed to you from your Lord is the truth, but most of the people do not believe (The Qur'ān, 13:1).

3 Seyyed Hossein Nasr, Ideals and Realities of Islam (Chicago: ABC International Group, Inc., 2000), pp. 38.

4 Blessed is He who sent down the Criterion upon His Servant that he may be to the worlds a warner (The Qur'ān, 25:1).

5 Alif, Lām, Rā. These are the verses of the wise Book (The Qur'ān, 10-1).

6 The Qur'ān, 3:58; 2:97; 10:57 and 4:174.

7 Indeed, in the creation of the heavens and the earth, and the alternation of the night and the day, and the [great] ships which sail through the sea with that which benefits people, and what Allah has sent down from the heavens of rain, giving life thereby to the earth after its lifelessness and dispersing therein every [kind of] moving creature, and [His] directing of the winds and the clouds controlled between the heaven and earth are signs for a people who use reason (The Qur'ān, 2:164).

8 Seyyed Hossein Nasr, Man and Nature: The Spiritual Crisis of Modern Man (Chicago: ABC International Group, Inc., 1997), pp. 94-95.

9 The Qur'ān, 47:19.

10 The Qur'ān, 21:25.

11 The Qur'ān, 3:18.
} 
Similarly, the verses describing diverse natural phenomena termed as the signs of God, employ terminology directly related to a cognitive perception that may lead one to the realisation of Divine unity. The phrases such as "then will you not reason?"; "then will they not see?"; "then will you not remember?", ${ }^{1}$ but also "then will they not believe?"; "then will you not be reverent?"; "then will they not be grateful?"2 come usually at the end of a particular verse describing the natural world as Divine signs that, if properly deciphered or understood in that aspect, will certainly lead one to the realisation of Divine unity and the wisdom underlying the creation as such. However, the Qur'ān suggests the same approach one should have towards reading and deciphering the text of the Qur'ān itself: \$Then do they not reflect upon the Qur'ān, or are there locks upon [their] hearts? ${ }^{3}{ }^{3}$ The linkage between reflection and heart in this verse visibly indicates a holistic approach towards a subject of the investigation that combines not only means of the cognitive faculties but also means of the spiritual intelligence of which heart (qalb) occupies its central place. ${ }^{4}$

\section{Affirmation}

The aforementioned dimensions of the Qur'ān were not only perfectly understood by the Prophet al-Rāshidun), but also exemplary manifested both, spiritually and intellectually. From the very beginning of his prophetic mission, the Prophetes spent most of his time teaching and educating his Companions, young and old, men and women, all the doctrines revealed in the Qur'ān for the entire period of revelation. By performing his prophetic task, the Prophets was also establishing the Islamic worldview with all its conceptual structures (life, world, knowledge, value, and man structure), ${ }^{5}$ which served as the necessary environment for the development of Islamic science and later, Islamic civilisation in all its diverse facets that were primarily based on the doctrines of the Qur'ān and the Sunnah of the Prophet)

\footnotetext{
The Qur'ān, 23:80; 32:27; 32:4.

The Qur'ān, 21:30; 10:31; 36:35.

The Qur'ān, 47:24.

4 The heart in this context is considered as "the seat of intelligence and the point which relates the terrestrial human state to the higher states being" (S.H. Nasr, Knowledge and the Sacred [Albany: State University of New York Press, 1989], pp. 174), or "the inner perceptive faculty" (Alparslan Açikgenç, Islamic Science: Towards a Definition [Kuala Lumpur: International Institute of Islamic Thought and Civilization, 1996], pp. 46. This understanding of heart is in accordance with the Qur'ānic perspective of human heart such as in the following verses: ...Are not heart in peace in the remembrance of God? (The Qur'ān, 13:28) and ...Truly it is not the eyes that go blind, but it is hearts within breasts that go blind (The Qur'ān, 22:46).

5 Alparslan Açikgenç, Ibid, pp. 21-25.
} 
After founding essential principles of the Islamic worldview during the Makkan period of Revelation, the Prophet broadened the worldview with intellectual as well as political activities in the Madinian period, wherein the first Muslim state was founded under the leadership of the Prophets himself. The careful examination of the Qur'ānic verses and its interpretation to the Companions, in addition to the newly emerging social and religious needs legally sanctioned by the Prophets in Madinah, corresponds to the process of development of any scientific worldview via three fundamental stages, namely, the abstraction, the concretization, and the actualisation. The abstraction refers to the accumulation of scientific knowledge produced by philosophers, scholars, and scientists. However, in the context of the Islamic worldview, it corresponds to the revelational knowledge in the Qur'ān. The concretisation stands for the manifestation of abstract knowledge by intellectuals, architects, and artists in their respective ways of exposing it to wider audiences. This task was performed by the Prophet and the earliest teachers among the Companions appointed by the Prophet dissemination of the abstract and concretised knowledge through educational institutions and media. This stage within the Islamic framework is represented by the early centres of educations i.e., from the Madinian mosque, serving as the main centre of education to scholarly circles founded by official teachers of the Qur'ān and Hadith scattered over different areas of the Islamic state. ${ }^{1}$

This early traditional system of learning will eventually embrace the constant progression, parallel to the development of Islamic Civilisation that many considered as the cradle of knowledge with numerous centres of learning from schools (madāris pl. of madrasah) to universities (jāmi'āt pl. of jāmi'ah) across the Islamic world, from the East to the West, much before the first universities are founded in Europe. ${ }^{2}$ Needless to say, this eagerness for knowledge, so obvious in various classes of Muslim scholars and scientists, has been nurtured by the Qur'ānic revelation and the Sunnatic tradition, which respectively, regarded the concept of knowledge as a necessary tool for human development in both, its spiritual and material aspects. The fact that the Qur'ān did not discourage Muslims to explore and enjoy the natural world and its beauty, but rather insisted on its exploration and

1 Muhammad Mustafa al-A'zami, The History of the Qur'ānic Text from Revelation to Compilation: A Comparative Study with the Old and New Testaments (Petaling Jaya: Islamic Book Trust, 2011), pp. 59-70; Studies in Hadith Methodology and Literature [Revised Edition] (Kuala Lumpur: Islamic Book Trust, 2002), pp. 14-44.

2 See the detailed account on Islamic education in Seyyed Hossein Nasr, Science and Civilization in Islam (Cambridge: The Islamic Texts Society, 1987), pp. 59-91. 
contemplation on its varied signs, created for the benefit of human beings, all that they might realise in it the unicity of the multiplicity, and eventually rejoin the nature in the constant remembrance of God. This dual dimension of the Qur'ānic revelation, namely, it is verbal (the Book) and natural (the Cosmos) manifestation provided the classical Muslim scholars and scientists with much energy and enthusiasm to study all aspects of both, microcosm and macrocosm in their physical and metaphysical realms only to discover therein the perfect reflection of Divine unity.

\section{Manifestation}

The establishment of the Madinian state after such a short period of time, since the first verses of the Qur'ān were revealed, may serve perhaps as the best indicator of the efficacy of the Islamic worldview, especially its knowledge structure, for it is precisely knowledge that determines one's spiritual or worldly status as the Qur'ān rhetorically asks: "What of one who is devoutly obedient during the watches of the night, prostrating and standing [in prayer], wary of the Hereafter and hoping for the Mercy of his Lord[...]? Say, Are those who know and those who do not know equal? Only possessors of intellect reflect.'. ${ }^{1}$. The verse, as it seems, refers to the state of the Prophet and his Companions who were in constant spiritual obedience and serenity in relation to God. These men were the possessors of knowledge which in this verse is termed as al-albāb (pl. of al-lubb, meaning "kernel," "pith" or "core"), that is the knowledge of the inner reality of things. ${ }^{2}$ The following verse adds even more to the conditions of the believers described earlier and the unfolding events awaiting them: "Say, 'O my servants who believe, reverence your Lord, for those who do good in this world there is good; and God's earth is vast, Surely those who are patient shall be paid their reward in full without reckoning. ${ }^{3}$

A detailed analysis of the early history of Islam - first the Makkan period, when the Prophet and his followers have endured all kinds of misery, abuse, and violence against them, resulting in an attempt to assassinate the Prophet followed by the Madinian period, when soon after settling in a new environment, the Prophet踩 was able to establish the Madinian polity and steadily gain political and economic power to conquer almost the entire Arabian Peninsula - reveal the most significant phase towards the creation of one of the most

\footnotetext{
1 The Qur'ān, 39:9.

2 Seyyed Hossein Nasr (Ed.), Ibid, pp. 1120-1121.

3 The Qur'ān, 39:10.
} 
influential civilisations in the world. Thus, the combination of knowledge and belief, reverence and patience in the foregoing verses, perfectly describe conditions of the Prophet and his devoted followers, setting an example for the generations of Muslims to follow. "And God's earth is vast" has indeed proven to be so, by the end of the first century of Islam, the borders of the Islamic empire reached far away to the Iberian Peninsula on the West and Indian subcontinent on the East.

Be it as it may, the Prophets successfully articulated the structures within the Islamic worldview formed in Makkah, through the newly emerging legal system of the Islamic governance in Madinah, that is, the Islamic law predicated on the individual and societal benefits, as it is intended to protect these benefits and facilitate improvement and perfection of the conditions of human life on earth. ${ }^{1}$ Thus, the aforementioned structures of the Islamic worldview have been implemented legally by means of Maqāșid al-Sharı’’ah or the aims and objectives of Islamic law which Muslim scholars have classified into three categories, namely, the essential (darüriyyāt), the conventional (hājijyyāt), and the ornamental (tahisinniyyāt). ${ }^{2}$ The essential objectives are five: faith, life, intellect, progeny, and wealth. Contextually, they perfectly correspond with the five structures of the Islamic worldview, namely, life, world, knowledge, value, and human being, that encompasses every domain of human life in this world, facilitating it at the same time, with means of salvation in the Hereafter.

These structures of the Islamic worldview merged with the Maqāșid of Islamic law were impeccably manifested by the first four caliphs who took the leadership of the Islamic state after the Prophete and followed the prophetic Sunnah as their exemplary model. They represented within the Muslim community not only successful individuals in their private occupational affairs but also in their spiritual and intellectual states as to be worthy of the leadership entrusted upon them. All four of them were huffāz al-Qur'ān and notable scholars of hadith who studied directly under the guidance of the Prophet for much of their lives. Each of them respectively has contributed to the subsequent progress of the Madinian polity in the twofold directions, namely its political, economic, and security outlook on the one hand, and its intellectual, spiritual, and scientific stance on the other. It is due to their

1 Mohammad Hashim Kamali, “Maqasid al-Shari’ah: The Objectives of Islamic Law,” Islamic Studies, Vol. 38, No. 2 (Summer 1999 ), pp. 193.

2 Muhammad Hashim Kamali, Ibid, pp. 195. 
exceptional wisdom and leadership that the early Muslim community was able to lay down firm and lasting foundations for the later advancement of Islamic civilisation.

\section{Conclusion}

Although the Qur'ān was not explicit on a specific nature and formation of the Islamic state, its emphasis on the Muslim Ummah as the best community brought forth unto mankind, enjoining right, forbidding wrong, and believing in God ${ }^{1}$ has revealed that the establishment of political and legislative authority in Islam rests on the Ummah (Muslim community) that represents the main audience and carrier of the Qur'ānic messages concerning benefits of Muslims and its attainment through the Maqāșid al-Sharı’’ah. On the other hand, by creating the Islamic worldview during the Makkan period of the Revelation, and by instituting the Islamic polity during the Madinian period, the Prophet has perfectly manifested the manner by which to carry on the implementation of rules pertaining to the Islamic governance in order that the Maqāșid of Islamic law is fully realised i.e., preserved and promoted individually and collectively within the Islamic state. The key factors for such an achievement and never to be devoid from each other, as emphasised earlier are the knowledge associated with the revelation, the affirmation symbolised by faith, and the manifestation related to the acquired knowledge and its spiritual and material application.

1 The Qur'ān, 3:110. 


\section{References}

Açikgenç, Alparslan. Islamic Science: Towards a Definition. Kuala Lumpur: International Institute of Islamic Thought and Civilization, 1996.

Al-A'zami, Muhammad Mustafa. The History of the Qur'ānic Text from Revelation to Compilation: A Comparative Study with the Old and New Testaments. Petaling Jaya: Islamic Book Trust, 2011.

Al-A'zami, Muhammad Mustafa. Studies in Hadith Methodology and Literature [Revised Edition]. Kuala Lumpur: Islamic Book Trust, 2002.

Kamali, Mohammad Hashim. Principles of Islamic Jurisprudence [Second Revised Edition]. Kuala Lumpur: IImiah Publishers, 2007.

Kamali, Mohammad Hashim. "Maqasid al-Shari'ah: The Objectives of Islamic Law," Islamic Studies, Vol. 38, No. 2, Summer 1999.

Leaman, Oliver (Ed.). The Qur'ān: An Encyclopedia. London: Routledge, 2006.

Nasr, Seyyed Hossein. Ideals and Realities of Islam. Chicago: ABC International Group, Inc., 2000.

Nasr, Seyyed Hossein. Knowledge and the Sacred. Albany: State University of New York Press, 1989.

Nasr, Seyyed Hossein. Man and Nature: The Spiritual Crisis of Modern Man. Chicago: ABC International Group, Inc., 1997.

Nasr, Seyyed Hossein. Science and Civilization in Islam. Cambridge: The Islamic Texts Society, 1987.

Nasr, Seyyed Hossein (Ed.). The Study Quran: A New Translation and Commentary. New York: HarpenOne, 2015.

Rosenthal, Franz. Knowledge Triumphant: The Concept of Knowledge in Medieval Islam. Leiden: Brill, 2007.

Saeed, Abdullah. The Qur'ān: An Introduction. London: Routledge, 2008. 